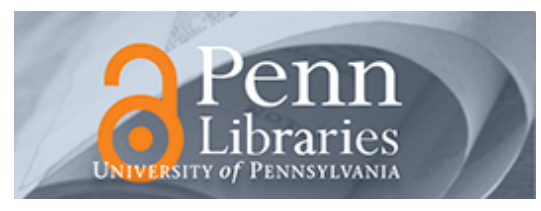

University of Pennsylvania ScholarlyCommons

\title{
Agency Problems of Excess Endowment Holdings in Not-for-Profit Firms
}

John E. Core

Wayne R. Guay

University of Pennsylvania

Rodrigo S. Verdi

Follow this and additional works at: https://repository.upenn.edu/accounting_papers

Part of the Accounting Commons

\section{Recommended Citation}

Core, J. E., Guay, W. R., \& Verdi, R. S. (2006). Agency Problems of Excess Endowment Holdings in Not-forProfit Firms. Journal of Accounting and Economics, 41 (3), 307-333. http://dx.doi.org/10.1016/ j.jacceco.2006.02.001

This paper is posted at ScholarlyCommons. https://repository.upenn.edu/accounting_papers/120

For more information, please contact repository@pobox.upenn.edu. 


\title{
Agency Problems of Excess Endowment Holdings in Not-for-Profit Firms
}

\begin{abstract}
We examine three alternative explanations for excess endowments in not-for-profit firms: (1) growth opportunities, (2) monitoring, or (3) agency problems. Inconsistent with growth opportunities, we find that most excess endowments are persistent over time, and that firms with persistent excess endowments do not exhibit higher growth in program expenses or investments. Inconsistent with better monitoring, program expenditures toward the charitable good are lower for firms with excess endowments, and CEO pay and total officer and director pay are greater for firms with excess endowments. Overall, we find that excess endowments are associated with greater agency problems.
\end{abstract}

\section{Keywords}

corporate governance, not-for-profit, cash holdings, endowment, agency problems

Disciplines

Accounting 


\title{
Agency problems of excess endowment holdings in not-for-profit firms
}

\author{
John E. Core* \\ Email: jcore@wharton.upenn.edu \\ Phone: (215) 898-4821 \\ Wayne R. Guay \\ Email: guay@wharton.upenn.edu \\ Phone: (215) 898-7775 \\ Rodrigo S. Verdi \\ Email: rverdi@wharton.upenn.edu \\ Phone: (215) 898-7783
}

All authors are at the Wharton School, University of Pennsylvania

1300 Steinberg Hall-Dietrich Hall

Current Version: December 15, 2005

\footnotetext{
* Corresponding author. We appreciate the comments and suggestions of seminar participants at Emory University, Ohio State University, the University of Oregon, the University of Utah, Washington University, the Wharton School, the 2004 Federal Reserve Bank of New York Not-for-profit Conference, and the 2005 American Accounting Association annual meeting. We also appreciate comments from, Rajesh Aggarwal (discussant), Denis Caplan, Diane DelGuercio, Tom Donaldson, Tom Dunfee, Jarrad Harford, S.P. Kothari (editor), David Larcker, Charlotte Pryor, Nicole Thorne-Smith, Bob Yetman, and an anonymous referee. We appreciate financial support from the Wharton School. Rodrigo Verdi is also grateful for financial support from the Deloitte \& Touche Foundation.
} 


\title{
Agency problems of excess endowment holdings in not-for-profit firms
}

\begin{abstract}
We examine three alternative explanations for excess endowments in not-for-profit firms: (1) growth opportunities, (2) monitoring, or (3) agency problems. Inconsistent with growth opportunities, we find that most excess endowments are persistent over time, and that firms with persistent excess endowments do not exhibit higher growth in program expenses or investments. Inconsistent with better monitoring, program expenditures toward the charitable good are lower for firms with excess endowments, and CEO pay and total officer and director pay are greater for firms with excess endowments. Overall, we find that excess endowments are associated with greater agency problems.
\end{abstract}

JEL classification: G31; G35; G38; J33; L31

Keywords: Corporate governance; Not-for-profit; Cash holdings; Endowment; Agency problems 


\section{Introduction}

Not-for-profit firms often maintain large endowments, and the determinants and consequences of this unusual feature have received little study. An endowment is a fund of cash and/or securities that the not-for-profit can use to finance current and future expenses. The purpose of this paper is to examine whether there are agency problems when not-for-profit firms (NFPs) hold excess endowment assets. ${ }^{1}$

We use as a basis of our study the literature that explores agency problems related to cash holdings in for-profit firms (e.g., Jensen, 1986). Evidence on whether excess cash results in agency problems in for-profit firms is mixed. Blanchard, Lopez-de-Silanes and Shleifer (1994) document excessive investment and acquisition activity for eleven firms that experience a large cash windfall due to a legal settlement, and Harford (1999) finds that firms with excess cash are more likely to make value-decreasing acquisitions. Further, Pinkowitz and Williamson (2004) show that the market valuation of a firm's cash holdings is lower when agency problems are likely to be greater. In contrast, Opler, Pinkowitz, Stulz and Williamson (1999) document only modest evidence of greater spending on new projects and acquisitions for a large sample of firms with high excess cash.

Whether cash-related agency problems are present to a greater or lesser extent in NFPs is an open question. On one hand, recent work by Fisman and Hubbard (2002) argues that donors serve an important monitoring role in NFPs and minimize agency costs. In addition, some of the more frequently cited cash-related agency problems in forprofit firms, such as excessive risk-reducing acquisitions, are likely to be less prevalent in

\footnotetext{
${ }^{1}$ From this point forward, we use the acronym NFP in place of "not-for-profit." In this paper, we use the terms "not-for-profit" and "nonprofit" as synonyms.
} 
not-for-profit firms. NFP managers may have weaker incentives to engage in riskreducing activities because less of their wealth is concentrated in firm-specific assets (i.e., the future compensation of both nonprofit and for-profit managers has a firm-specific element, but for-profit managers also have a large proportion of their wealth invested in firm-specific stock and options).

On the other hand, cash-related agency problems are potentially exacerbated in NFPs because unlike for-profits, NFPs have no residual claimants with strong monitoring incentives. Further, cash endowment holdings by NFPs are, on average, substantially larger than cash holdings by for-profits. In the spirit of Jensen (1986), Hansmann (1990, p. 36) suggests that to ensure private benefits such as a light workload and increased job security, NFP managers can have incentives to build endowments rather than provide current services. $^{2}$ Finally, there is no feasible method of returning unnecessary cash holdings to donors. In other words, there is no analogue to the dividends and share repurchases that for-profit firms use to return funds to shareholders.

Unlike shareholders in public firms, excess cash holdings can be costly to NFP donors even when agency problems and transaction costs are low. In the absence of agency problems and transaction costs, excess cash is not costly for public firm shareholders: The extra cash lowers risk and expected return, and shareholders can access the funds if needed by borrowing against the value of their shares. However, in NFPs, excess cash holdings have an opportunity cost for donors: Donors have no ability to borrow against these holdings and use the cash to fund projects in other areas or industries. Thus, to the extent that an NFP holds cash in excess of its own needs, other

\footnotetext{
2 This suggestion is one of many reasons Hansmann (1990) discusses for why universities may hold endowments.
} 
NFPs can be under-funded. ${ }^{3}$

We examine endowments in a broad sample of NFPs over the period from 1992 to 2001. We use the model developed by Fisman and Hubbard (2002) to form expectations about firm-specific benchmark levels of endowment. We estimate a firm's excess endowment as the residual from yearly regressions based on this model. An excess endowment can mean: (1) an endowment that is optimally larger in anticipation of firmspecific growth opportunities; (2) an endowment that is optimally larger because of superior firm-specific monitoring; or (3) an endowment that is sub-optimally larger due to firm-specific agency problems. Our tests are designed to distinguish between these explanations.

Inconsistent with large endowments anticipating greater firm-specific growth opportunities, we find that most firms with excess endowments maintain their excess endowments for several years (i.e., they do not draw down their endowments to fund growth). Furthermore, we find that firms with persistent excess endowments do not exhibit higher growth in program expenses or investments. We conclude that growth opportunities are unlikely to explain excess endowments for most NFPs, and that the large endowments suggest either better monitoring or agency problems.

To distinguish between firm-specific better monitoring and agency problems as potential explanations for excess endowments, we first examine the relation between excess endowments and firm efficiency, which we measure using program expenses as a fraction of total expenses (the program expense ratio). This ratio is a widely used proxy for the efficiency with which total expenses are made toward charity instead of toward

\footnotetext{
${ }^{3}$ Hansmann (1980, pp. 14-19) discusses the trade-off of the costs and benefits of deferring charitable spending.
} 
fundraising and administration. Consistent with greater agency problems in firms with excess endowment, we find that the program expense ratio is lower for firms with excess endowments. As a second test to distinguish between the better monitoring and agency problem explanations, we examine the relation between excess endowments and CEO and total officer and director pay as proxies for private benefits accruing to management. We find a positive association between excess endowments and compensation, which again is inconsistent with the better monitoring explanation. Our overall evidence suggests that excess endowments are associated with greater agency problems.

Our research builds on recent work by Fisman and Hubbard (2002). Like Fisman and Hubbard, we assume donors wish to maximize the efficiency with which charitable goods are delivered over time. To do this, donors choose an endowment size that maximizes (1) the benefits of endowment funds as a buffer to smooth production of the charitable good, net of (2) the agency costs of endowment funds, which include delays in the provision of the charitable good to beneficiaries and the potential for managers to divert assets for their private benefit.

In contrast to Fisman and Hubbard's (2002) emphasis on modeling expected endowments, our focus is on examining the consequences of excess endowments, and whether they are associated with agency problems. This approach is similar to that of Harford (1999) and Opler et al. (1999), who recognize that the target level of cash holdings is expected to vary cross-sectionally in for-profit firms, but that deviations from target levels do sometimes exist and can be associated with agency problems. Our findings are consistent with the for-profit literature that documents agency problems in firms with excess cash holdings. However, unlike the for-profit literature, we find no 
evidence that managers use excess endowments to increase investment. Instead, excess endowments are highly persistent over time, much more so than in for-profit firms.

The remainder of this paper is organized as follows. In Section 2, we offer background on NFPs and review the related literature. We define our hypotheses in Section 3. We describe our data and research design in Section 4, and present the results of our tests in Section 5. We provide sensitivity tests of our results in Section 6. In Section 7 , we provide a summary and concluding remarks.

\section{Background on charitable not-for-profits and literature review}

The defining feature of not-for-profit organizations is not that they cannot make profits - in fact, many do - it is that they are prohibited from distributing their profits to anyone who exercises control over the firm (Hansmann, 1980, 1996). This "nondistribution constraint" means that no parties have a claim to a NFP's residual earnings. Consequently, NFPs have no shareholders and cannot issue equity.

However, "instead of issuing shares, NFPs can raise "equity" through contributions from donors (Gentry, 2002, p. 847). Analogous to cash and marketable securities in a for-profit firm, the endowment consists of past donations, past profits, and other capital that has been accumulated, but not expended, in the NFP's operations. Thus, similar to a shareholder in a for-profit firm, a donor provides equity capital, but unlike the shareholder, the donor has no ability to require the return of that capital if cash balances grow too large. Further, because the endowment comes from current and past donors, it would be difficult for the NFP to return donations even if it so desired. Finally, adverse tax consequences to the donors likely render any return of cash to donors undesirable. 
The fact that NFPs have no residual claimants does not imply that these organizations are without effective monitors. Donors, particularly those making large contributions, often have control rights over the firms even though they do not have residual claims. For example, large donors often sit on NFP boards (Fama and Jensen, 1983). The fact that large donors have chosen to invest their private capital in a particular NFP also suggests that these benefactors have a stake in effectively carrying out the NFP's mission.

Hansmann (1990), in a discussion of university endowments, examines a number of reasons why a NFP may accumulate endowment assets. One reason offered is precautionary savings - the endowment assets provide a "financial buffer" (p. 39) against periods of financial adversity, and allow the firm to maintain a constant level of services in the face of fluctuating expenses and income from donations and other sources. This precautionary savings explanation is similar to the theory in the for-profit literature to explain corporate cash holdings (e.g., Myers and Majluf, 1984; Harford, 1999; Opler et al., 1999).

Fisman and Hubbard (2002) formalize a model of optimal endowment size where firms trade off the benefits of precautionary savings as a buffer to smooth production against the agency costs of endowment funds. They predict and find that donors allow firms to hold larger endowments when their operating environment is characterized by highly uncertain cash flows, limited alternative sources of financing, and large fixed costs. These determinants are analogous to the for-profit literature on corporate cash holdings (Harford, 1999; Opler et al., 1999), where firms bear costs when they experience a shortage of funds necessary to carry out their operating and investing 
activities. As discussed below, we use the Fisman and Hubbard (2002) model to estimate expected endowment levels in NFPs.

\section{Hypothesis development}

Holding aside temporary shocks to donations or revenues, there are three reasons that an NFP can hold an endowment that is larger than predicted by the Fisman and Hubbard model. First, the Fisman and Hubbard model does not control for growth options, and it can be optimal for an NFP to build a large endowment to fund anticipated growth. For example, before constructing a building, an NFP may save for a portion of the cost in its endowment. A second reason that a firm can hold an excess endowment is because of firm-specific advantages in monitoring management's use of endowment funds. Fisman and Hubbard predict that when monitoring quality is high, donors may allow NFP managers to hold larger than normal endowments because the donors are less concerned about the agency costs of excess endowments. On the other hand, high monitoring quality may indicate that donors are able to prevent managers from holding excess endowments (Opler et al. 1999, p. 12). A third reason for excess endowments is agency problems.

We expect that when donors are active and efficient monitors, NFP endowments are optimal, on average. However, similar to the arguments made by Harford (1999) and Opler et al. (1999) about cash holdings in the for-profit literature and by Hansmann (1990) in the NFP literature, we predict that managers attempt to increase the endowment beyond the optimal level so as to increase their scope for discretion. Further, consistent with Blanchard, Lopez-de-Silanes and Shleifer's (1994) findings on firms experiencing cash flow windfalls, we note that a positive exogenous shock to cash flows or asset value 
can also increase the endowment and, in turn, increase managers' scope for discretion. Thus, excess endowments can signal the existence of agency problems. ${ }^{4}$

Managers of NFPs have four primary options when faced with excess endowment assets: (1) continue to hold the excess endowment assets; (2) invest in fixed assets that expand the production capacity of the firm; (3) increase program expenditures; or (4) consume assets for their private benefit in the form of excess compensation or perquisites. We examine how managers use excess assets and provide evidence on whether the excess assets are the consequence of growth options or better monitoring, or if they instead reflect agency problems.

If excess endowments primarily occur because of anticipated growth opportunities, we do not expect excess endowments to be persistent. To provide evidence on whether excess endowments are associated with growth opportunities, we examine whether firms with excess endowments increase program expenses at a faster rate and make greater investments in fixed assets than firms with smaller endowments. When managers increase program expenses, it is clear that they act in donors' interests. Growth in fixed assets is more ambiguous, since managers may invest optimally to expand the scope of the programs they offer, or they may over-invest as a means of increasing perquisite consumption. We will interpret increases in both program expenses and investment as evidence of realized growth options. On the other hand, if we find that excess endowments are persistent, and that firms with persistent excess endowments do

\footnotetext{
${ }^{4}$ Although our maintained assumption is that donors seek to maximize the efficiency of charitable services, it is important to note that not all donors will have this preference. Some donors may wish to use the charity as a vehicle for their own private consumption, and may as a result prefer a build-up of endowment assets. (Analogously in a public firm, one can imagine that a large shareholder, because of induced risk aversion, could prefer that the firm maintain large cash holdings.) For example, some donors may contribute assets and restrict their use so that the donor's name may be prominently displayed by the NFP for a long period of time. To address this possibility, we examine unrestricted endowment assets in sensitivity tests below.
} 
not invest nor increase program expenses, this suggests that growth opportunities are not the reason for excess endowments. In this case, larger than usual endowments suggest either better than usual monitoring or the existence of agency problems.

To distinguish between better monitoring and agency problems, we examine the relation between excess endowments and firm efficiency. Our proxy for firm efficiency is program expenses as a fraction of total expenses (the sum of program, fundraising, and administrative expenses). This program expense ratio measures the efficiency with which total expenses are made toward production of the charitable good (programs) instead of being used for fundraising and administration. The program expense ratio is a widely used measure of efficiency in NFPs (e.g., Weisbrod and Dominguez, 1986; Posnett and Sandler, 1989; Tinkelman, 1998 and 1999; Baber, Daniel and Roberts, 2002; Krishnan, Yetman and Yetman, 2004), and has been used in prior studies examining the relation between governance quality and NFP performance (e.g., Callen, Klein, and Tinkelman, 2003; Desai and Yetman, 2005). If excess endowments signal better monitoring, we expect a positive, or no, relation between excess endowments and the program expense ratio. This follows because better monitoring should prevent potential inefficiencies that might otherwise result from holding large endowments. On the other hand, a finding of a negative relation between excess endowment assets and the program expense ratio is inconsistent with better monitoring, and suggests greater agency problems. We test the following hypothesis stated in null form:

H1: The ratio of program expenses to total expenses is unrelated to firms' excess endowment assets, ceteris paribus.

If we find that firms with excess endowments operate less efficiently, it is interesting to consider how managers benefit from these agency problems. We expect 
that if excess endowments are associated with greater agency problems, managers will either shirk or consume assets for their private benefit in the form of excess compensation or perquisites. Fisman and Hubbard $(2002$, p.8) allude to these types of endowmentrelated agency problems by their assumption "that it is easier for managers to pursue personal interests with endowment funds rather than streams of revenue." With respect to compensation, we test the following hypothesis, again stated in null form:

H2: Managerial compensation is unrelated to firms' excess endowment assets, ceteris paribus.

In addition to testing for a relation between agency problems and managerial compensation, it would be interesting to examine the relation between agency problems and managerial perquisite consumption. As described below, our compensation measure does include monetary values for perquisites such as the personal use of housing or automobiles. However, we do not have data on perquisites such as a light workload and increased job security. Because we are conducting our study within NFP firms, we expect that even though these managers may receive lower pay than at similar for-profit firms, their direct pay including tangible perquisites is an important part of their compensation and may contain evidence about agency problems.

\section{Sample selection and data description}

We use a sample of charitable not-for-profit organizations (also known as 501(c)(3) tax-exempt organizations). Although these firms are tax-exempt, they must file an annual Form 990 with the IRS, and we use data from these returns. A database of NFP filings is provided by the National Center for Charitable Statistics (NCCS) through the Statistics of Income (SOI) files of the IRS for the years 1982 to 2001. We restrict our attention to the years beginning in 1992 when CEO compensation became available. 
These data contain all 501(c)(3) organizations with more than $\$ 10$ million in assets plus a random sample of about 4,000 smaller organizations. Our beginning sample consists of 124,752 firm-year organizations from 1992 to 2001. We exclude grant-making foundations, mutual organizations, and organizations whose industry is "unknown" (classified as ' $T$ ', ' $Y$ ', and ' $Z$ ' respectively by the National Taxonomy of Exempt Entities (NTEE) industry classification system).

We delete observations with apparent coding errors: those that report negative values of total contributions, total revenues, program expenses, total expenses, investment securities, total assets, total liabilities and top officer compensation. We also exclude observations that do not have the four prior years of data that we need to compute volatility of total revenue (a control in the endowment model described in the next section). This restriction reduces the sample size to 91,140 observations. From this sample, we match 49,556 firm-year observations with available CEO compensation data. The CEO compensation data is not available from the NCCS for all firms, and the reduction in our sample size is similar to the reduction in Fisman and Hubbard (2002) and Hallock (2002). Finally, we delete 7,804 firm-year observations that report CEO compensation, but not compensation for all officers as a group, since this is a logical inconsistency and apparent data error. The final sample used to estimate the endowment model shown in Equation (1) below consists of 41,752 firm-year observations from 8,727 different organizations.

Table 1 presents the distribution of observations for the four major industries according to the NTEE industry classification. As in Fisman and Hubbard (2002) and in Hallock (2002), our sample is concentrated in Health (35.6\%) and Education (26.1\%). 
The table presents median values for endowment as a multiple of total expenses. This measure can be interpreted as the number of years that the organization would be able to fund its expenses without additional revenues. Median endowment scaled by expenses ranges from a low of 0.24 for 'Health' firms up to 1.34 for 'Arts' firms. In contrast, existing research documents much smaller cash holdings in for-profit firms. For example, Opler et al. (1999) report median cash holdings scaled by non-cash assets of 0.065 across their sample of for-profit firms, which is much smaller than the median endowment scaled by non-endowment assets of 0.47 in our sample (untabulated).

The remaining columns present median data on total revenues, total expenses, investment growth, program expense growth, program expenses, CEO compensation, and officer and director compensation. Median investment growth (program expense growth) ranges from $4 \%(4 \%)$ of total expenses in the 'Arts' industry to $7 \%(5 \%)$ in the 'Education' industry. Median program expenses as a fraction of total expenses is the smallest in the 'Arts' industry at $75.64 \%$ and the largest in the 'Human Services' industry at $86.39 \%$. Median CEO compensation ranges from a high of $\$ 215,520$ in the 'Health' industry to a low of $\$ 104,140$ in the 'Human Services' industry. These across-industry differences emphasize the importance of controlling for industry variation in endowments, program expenses, and compensation. Finally, the table also presents descriptive statistics for the total sample.

\section{Insert Table 1 here}

\section{Methodology and results}

\subsection{Expectation model for endowment size}

We estimate a benchmark model for endowment that follows Fisman and 
Hubbard (2002) and is analogous to the model estimated for public firms by Opler et al. (1999). We expect endowments to be larger in firms with more uncertain cash flows, in smaller firms, and in firms with limited alternative sources of financing.

Consistent with Fisman and Hubbard, we model the ratio of endowment to total expenses. We measure endowment (Endow/Exp) as the sum of cash, savings, and investment securities (line 45, column (b) + line 46, column (b) + line 54, column (b)) deflated by total expenses (line 17). ${ }^{5}$ Because we are interested in the potential agency costs of excess liquid assets, and to be consistent with the for-profit literature on agency costs of excess cash holdings, we exclude less liquid assets such as inventory, land, buildings, and equipment.

Firms with uncertain cash flows require a greater buffer of precautionary funds. We proxy for cash flow uncertainty using the coefficient of variation of total revenue (CVREV) (line 12). CVREV is the ratio of the standard deviation of total revenue to mean total revenue, both measured over the five years ending at year $t$. We require at least four annual observations of total revenues prior to year $t$ for our computation, and if less historical data are available, we delete the observation.

Firms with alternative financing sources require less precautionary funds. We proxy for access to financing sources using an Access to Debt variable coded ' 1 ' if the firm has obtained debt in the last ten years ending at year $t$, and ' 0 ' otherwise. We categorize a firm as having debt if the firm reports tax-exempt bond liabilities (line 64a, column (b)) or mortgages and other notes payable (line 64b, column (b)). Following Fisman and Hubbard, we also interact the Access to Debt variable with CVREV with the

\footnotetext{
${ }^{5}$ Line numbers refer to lines on the IRS Form 990.
} 
expectation that cash flow uncertainty requires a smaller buffer of funds when firms have access to alternative financing sources.

We control for variation in monitoring across states using state fixed effects in the model. These indicator variables also control for state-specific differences in donor income and firm growth opportunities. Fisman and Hubbard (2002) proxy for monitoring with an index of state regulatory oversight, and Desai and Yetman (2005) proxy for monitoring with indices of state-level legal and reporting requirements. Because these indices of regulation, legal and reporting requirements are count variables of state level attributes, they can be expressed as linear combinations of state indicator variables. Accordingly, our state indicators capture the same variation in monitoring as these other indices. ${ }^{6}$

Firms with more cash inflows may temporarily hold more cash, and larger firms need less precautionary savings (Opler et al., 1999). We control for these size effects using the natural logarithm of total revenue (line 12). In addition to state effects, we also control for industry and year fixed effects in the model. The industry (year) effects control for industry-specific (year-specific) differences in donor income, regulation and monitoring, and firm growth opportunities. The benchmark endowment regression is:

$$
\begin{aligned}
& \text { Endow } / \operatorname{Exp}_{i t}=\beta_{0}+\beta_{1}{ }^{*} \mathrm{CVREV}_{i t}+\beta_{2}{ }^{*} \operatorname{LogRevenue}_{i t}+\beta_{3}{ }^{*} \text { Access to Debt }{ }_{i t} \\
& \left.+\beta_{4} * \text { Access to Debt }_{i t}\right) * \text { CVREV }_{i t}+\Sigma \beta_{\mathrm{j}} * \text { State }_{\mathrm{j}}+\Sigma \beta_{\mathrm{m}} * \text { Industry }_{\mathrm{m}}+\varepsilon_{i t} \text {. }
\end{aligned}
$$

We winsorize all variables by year at the $1 \%$ and $99 \%$ levels (i.e., for each variable we re-assign its value if it is less (greater) than the $1^{\text {st }}\left(99^{\text {th }}\right)$ percentile to the value of the $1^{\text {st }}\left(99^{\text {th }}\right)$ percentile in a given year) to mitigate the influence of outliers.

\footnotetext{
${ }^{6}$ Because the state indicators capture differences across states in monitoring, as well as differences in income, growth, and other factors, they cannot be directly interpreted as monitoring effects as the indices can; however, this interpretation is not a focus for our study.
} 
Table 2 - Column I presents the results of the expectation model for endowments described by Equation (1). Year, state, and industry dummies are included in the regression models but are not tabulated. In all regression specifications, we use HuberWhite robust standard errors clustered by firm. These standard errors are a generalization of the White (1980) standard errors and are robust to both serial correlation and heteroskedasticity (Rogers, 1993). All explanatory variables are statistically significant in the predicted direction. The total explanatory power of the model (R-square of $23.7 \%$ ) is comparable to R-squares ranging from $23 \%$ to $24 \%$ in Fishman and Hubbard's (2002) Table 4 . The results support the precautionary savings theory of endowment, in which firms with more volatile cash flows accumulate larger endowments, and large firms and firms with access to debt have lower endowment levels. Finally, we find that the interaction between the Access to Debt and CVREV is negative and significant, consistent with the hypothesis that access to finance alleviates the necessity to accumulate endowment in order to self-protect from cash-flow volatility. ${ }^{7}$

Because variable costs can be cut quickly in the event of financial distress, Fisman and Hubbard also predict that endowments are smaller for firms with a greater proportion of variable costs. To proxy for lower variable costs within the organization, they compute a labor intensity variable, and predict a negative association between this variable and endowment. We do not include this variable in our primary model because one of our hypotheses predicts that excess endowments are associated with compensation-related agency problems, and total wages is potentially a measure of

\footnotetext{
${ }^{7}$ A concern with the Access to Debt variable is that it may be endogenous to endowments, i.e., a larger endowment makes it easier to obtain debt. To address this concern, we remove the Access to Debt variable, and estimate the remainder of the endowment model as a reduced form. If we use this model for computing abnormal endowment, all of our results below in Tables 3 to 8 are qualitatively the same.
} 
agency problems (Bertrand and Mullanaithan, 2003). However, for comparison with Fisman and Hubbard, in Column II we tabulate the endowment model including labor intensity $(L A B O R \%)$, measured as total compensation for all employees including salaries, pension plan contributions, benefits and taxes (lines $25+26+27+28+29$, column (a)). We express this variable as a percentage of total expenses (line 17). As expected, $L A B O R \%$ is negatively related to endowment. The estimated coefficients for the remaining variables are very similar to the ones reported in Column I, and have the expected sign. In sensitivity tests, we find that none of our inferences are affected if instead we use the model in Column II to obtain our estimates of excess endowments.

We consider the regression in Table 2 - Column I to be a reasonable expectations model for the benchmark endowment held by a firm. We estimate a firm's excess endowment as the residual from yearly regressions using this model. That is, a firm with a positive (negative) residual in a given year is assumed to hold more (less) endowment than the benchmark level. As discussed above, a residual endowment can mean: (1) an endowment that is optimally larger because of firm-specific growth opportunities; (2) an endowment that is optimally larger because firm-specific monitoring is better; or (3) an endowment that is sub-optimally larger that can indicate firm-specific agency problems. Our empirical tests in the next two sections are designed to distinguish these alternatives.

\section{Insert Table 2 here}

\subsection{The association between excess endowments and growth opportunities}

To examine whether excess endowments are associated with growth opportunities, we follow Opler et al. (1999) and examine the persistence of excess endowments over time. We divide our sample firms into quartiles based on excess 
endowment every year. We then track the firms over the next five years to determine which excess endowment quartile the firm belongs to in the subsequent years.

In Table 3, we present the persistence of excess endowment for firms selected based on the first time they enter the highest quartile of excess endowment. We find that $74.7 \%$ of the high endowment firms remain in the top quartile of excess endowment in the following year, and $62.2 \%$ of the high endowment firms remain in the top quartile group five years later. The persistence of excess endowment is substantially higher than the persistence of excess cash holdings documented in for-profit firms by Opler et al. (1999), who find that only $39 \%$ of the for-profit firms remain in the top quartile group five years later.

\section{Insert Table 3 here}

The results in Table 3 are not consistent with the explanation that excess endowments are built up in anticipation of growth opportunities. To further investigate whether excess endowments are associated with growth opportunities, we examine growth in investment and growth in program expenses over one- and two-year periods following the measurement of excess endowment. We measure investments in property, plant, and equipment (PPE GR) as the change in land, buildings, and equipment (line 57a, column (b)) plus depreciation (line 42, column (a)). PROGRAM GR is the change in program services expenses (line 13). We compute PPE GR and PROGRAM GR for both one year (from year $t-1$ to $t$ ) and two years (from $t-1$ to $t+1$ ). To compare the growth across firms, we divide each measure by total expenses (line 17) at year t-1, and multiply it by 100 to express it as a percentage of total expenses.

To examine the relation between excess endowment and growth, we use 
regression models of the following form:

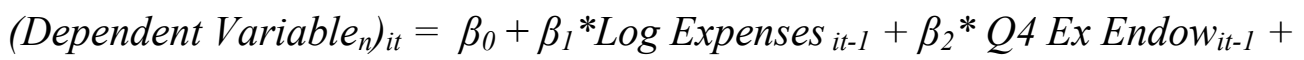

$$
\Sigma \beta_{\mathrm{t}} * \text { Year }_{\mathrm{t}}+\Sigma \beta_{\mathrm{j}} * \text { State }_{\mathrm{j}}+\Sigma \beta_{\mathrm{m}} * \text { Industry }_{\mathrm{m}}+\varepsilon_{i \text { t }} \text {. }
$$

where Dependent Variable $_{n}$ represents either PPE GR\% or PROGRAM GR\%. Q4 Ex Endow $_{i t-1}$ is an indicator variable that indicates an excess endowment: It is coded as ' 1 ' if the excess endowment is in the top quartile of the distribution in the year it is measured,

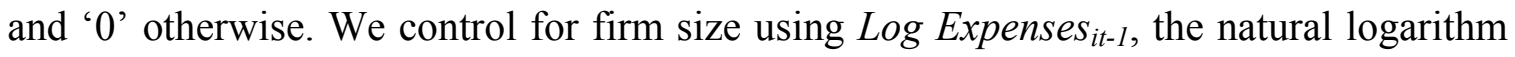
of prior-year total expenses (line 17). We also control for year, state, and industry fixed effects in the model.

The first (fourth) column of Table 4 shows the results of estimating Equation (2) with one-year PPE GR\% (one-year PROGRAM GR\%) as the dependent variable. In each case, the regression indicates that firms with endowments in the upper quartile invest about $2 \%$ of expenses more in new PPE and add about $2 \%$ more in new program expenses than do the remaining three quartiles of firms with smaller endowments.

To explore whether this extra investment is attributable to firms with transitory excess endowments, we partition firms into a persistent excess endowment group (Persistent Ex Endow $w_{\mathrm{t}-1}$ ) and a transitory excess endowment group (Transitory Ex Endow $\left.w_{\mathrm{t}-1}\right)$. We code an excess endowment as persistent if it remains in the top quartile of the distribution two years ahead, and transitory otherwise. The second and fifth columns of Table 4 show the results of estimating regressions for one-year PPE GR\% and oneyear PROGRAM GR\% respectively, that distinguish between persistent and transitory endowments. The number of observations is smaller in these regressions because of the requirement that we observe endowment at $t+1$. Consistent with a build-up and 
subsequent liquidation of endowments to fund growth, firms with transitory endowments show significantly greater one-year growth in investments and program expenses. The third and sixth columns show that these firms exhibit significantly greater two-year growth as well.

In contrast, firms with persistent excess endowments do not show substantial growth in investment or program. Two-year growth rates are not significantly different from zero. Although there is a significant one-year growth rates in program expenses firms with persistent excess endowments, its magnitude of $0.69 \%$ is economically small.

\section{Insert Table 4 here}

To summarize this section, we find that for most firms with excess endowments, the excess endowments are persistent. Firms with persistent excess endowments do not invest more nor increase program expenses. This evidence suggests that growth opportunities are not the reason for excess endowments for most firms. For these firms, large endowments suggest either better monitoring or agency problems.

\subsection{Tests to discriminate between better monitoring and agency problems}

To distinguish between better monitoring and agency problems, we conduct tests of Hypotheses 1 and 2 that examine the relation between excess endowments and both program expenses and executive compensation. To test Hypothesis 1, we measure the program expense ratio, PROG EXP RATIO, as total program services expenses (line 13) as a percentage of total expenses (line 17). As discussed above, this ratio is widely used as a measure of efficiency and performance both by donors and by previous researchers. A high proportion of program expenses to total expenses, which is the same as a low proportion of management, general and fundraising expenses to total expenses, means 
that the organization is efficiently delivering services to maximize the charitable good.

To test Hypothesis 2, we construct two measures of managerial compensation. Our first measure is total CEO compensation, CEO COMP, computed as the natural logarithm of CEO compensation. This measure includes: (1) "salary, fees, and bonuses" (Part V, column (c)), (2) contributions to employee benefit plans and deferred compensation (Part V, column (d)), and (3) expense account and other ${ }^{8}$ (Part V, column (e)). ${ }^{9}$ Second, we compute the fraction of total expenses attributable to the compensation of top executives. $O \& D C O M P \%$ is officer and director compensation (line 25 , column (a)) as a percentage of total expenses (line 17).

We examine the association between excess endowment and the three dependent variables using regression models of the following form:

$(\text { Dependent Variable })_{i t}=\beta_{0}+\beta_{1} *$ Controls $+\beta_{2} *$ Ex Endow $_{i t-1}$ $+\Sigma \beta_{\mathrm{t}} *$ Year $_{\mathrm{t}}+\Sigma \beta_{\mathrm{j}} *$ State $_{\mathrm{j}}+\Sigma \beta_{\mathrm{m}} *$ Industry $_{\mathrm{m}}+\varepsilon_{i t}$.

$\left(\text { Dependent } \text { Variable }_{n}\right)_{i t}=\beta_{0}+\beta_{1} *$ Controls $+\beta_{2}{ }^{*}$ Positive Ex Endow Et-I $_{3}+$ $\beta_{3}{ }^{*}$ Negative Ex Endow ${ }_{i t-1}+$ $\Sigma \beta_{\mathrm{t}} *$ Year $_{\mathrm{t}}+\Sigma \beta_{\mathrm{j}} *$ State $_{\mathrm{j}}+\Sigma \beta_{\mathrm{m}} *$ Industry $_{\mathrm{m}}+\varepsilon_{i t}$.

$\left(\text { Dependent } \text { Variable }_{n}\right)_{i t}=\beta_{0}+\beta_{1} *$ Controls $+\beta_{2} * Q 4$ Ex Endow $_{i t-1}+$ $\Sigma \beta_{\mathrm{t}} *$ Year $_{\mathrm{t}}+\Sigma \beta_{\mathrm{j}} *$ State $_{\mathrm{j}}+\Sigma \beta_{\mathrm{m}} *$ Industry $_{\mathrm{m}}+\varepsilon_{\text {it }}$.

where Dependent Variable $_{n}$ represents either PROG EXP RATIO, CEO COMP, or O\&D COMP\%.

In Model (3), we use a continuous measure of the excess endowment measure, $E x$ Endow $_{i t-1}$, which is simply the residual from the benchmark endowment model described

\footnotetext{
${ }^{8}$ As described in the instructions to IRS Form 990, this amount includes expense account reimbursements and perquisites such as "the value of the personal use of housing, automobiles, or other assets owned or leased by the organization (or provided for the organization's use without charge), as well as any taxable or nontaxable fringe benefits)."

9 "Part" positions refer to parts of IRS Form 990.
} 
by Equation (1). Model (4) is a spline regression with an inflection point at zero. Positive (Negative) Ex Endow $w_{i t-1}$ is Ex Endow it-l $_{1}$ if Ex Endow it-l $_{1}$ is positive (negative or 0), and '0' otherwise. This specification is consistent with Opler et al.'s (1999) capital expenditure regressions that allow different coefficients on positive and negative excess cash holdings (see their Table 8, pp. 36-37). In Model (5), we measure excess endowment as an indicator variable, Q4 Ex Endow $w_{i t-1}$, coded as '1' if the excess endowment is in the top quartile of the distribution in the year it is measured, and ' 0 ' otherwise. Under the assumption that we measure excess endowment with error, as compared to a continuous measure, this variable may allow for a more powerful test of whether agency problems are more severe in firms with the largest excess endowments. This last approach follows Opler et al. (1999) who find that capital expenditures and acquisitions are greatest in the highest quartile of excess cash holdings, and Harford (1999) who examines characteristics of "cash rich" firms with very large excess cash holdings.

We expect the coefficients on Ex Endow $w_{i t-1}$ and $Q 4$ Ex Endow $w_{i t-1}$ to be negatively related to PROG EXP RATIO it if there are agency problems. This follows because firms with agency problems have lower operating efficiency. We predict that the sign of the coefficient on Positive Ex Endow it-I $_{1}$ is negative, and the sign of the coefficient on Negative Ex Endow $w_{i-1}$ is zero. Like Opler et al. (1999), we expect that cash-related agency problems reside primarily in firms with excess cash holdings.

When $C E O C O M P_{i t}$ and $O \& D C O M P \%_{i t}$ are the dependent variables, we expect the coefficients on Ex Endow $w_{i t-1}$ and $Q 4$ Ex Endow $w_{i t-I}$ to be positive if firms with large excess endowments suffer from agency problems that result in excess managerial compensation. Based on our expectation that cash-related agency problems reside 
primarily in firms with excess cash holdings, we predict the sign of the coefficient on Positive Ex Endow it-I $_{1}$ is positive, and the sign of the coefficient on Negative Ex Endow it- 1 is zero.

In each model, Controls refers to our control variables for the expected level of each dependent variable in the absence of agency problems. We expect that firm size, industry membership, and location are important determinants of all of the dependent variables. We control for firm size using Log Expenses $_{i t-1}$, the natural logarithm of prioryear total expenses (line 17). As above, we control for variation in monitoring across states using state fixed effects in the model. These indicator variables also help control for state-specific differences in donor income and firm growth opportunities. We also include industry effects in all models to help control for industry-specific differences in income, regulation and monitoring, and firm growth opportunities. Finally, we include year indicators in the regression to control for differences over time.

In addition, in the program expense ratio regressions, we include controls for potential manipulation of program expense accounting. Krishnan et al. (2004) present evidence consistent with charities overstating program expenses to appear more efficient, and with weaker charities engaging in more of this manipulation. A potential concern with our tests is that a negative relation between excess endowments and program expenses could reflect upward manipulation by under-endowed firms (weaker firms) rather than inefficiency by over-endowed firms. To address this concern, we include as controls the two variables Krishnan et al. show to be associated with manipulation: (1) Contributions $\%$ it-I (the ratio of total contributions (line 1d) to total revenue (line 12)), and (2) Liabilities $_{\text {it- } 1}$ (total liabilities (line 66) divided by total assets (line 59)). Total 
contributions includes both private donations from individuals and corporate, and government grants.

In the compensation regressions, we include a control for performance. Hallock (2002) finds that outside fundraising is the performance measure that best explains CEO compensation in NFPs. Thus, in the CEO COMP ${ }_{i t}$ and $O \& D C O M P \%_{i t}$ regressions, we follow Hallock (2002) and use the logarithm of total contributions (line 1d) in the current year to control for outside fundraising in addition to our controls for size, industry, year, and state effects. ${ }^{10}$ To avoid losing 4,508 observations due to taking the logarithm of zero, we include an indicator variable, Zero Contributions $s_{i t}$, equal to 1 if outside fundraising is zero, and 0 otherwise. We then measure $\log$ Contributions $_{i t}$ as the log of total contributions if positive, and 0 otherwise. In sensitivity tests, we also include an additional control for growth opportunities in our pay regressions by including the oneyear-ahead realized percentage change in program expenditures.

All variables in Equations (3), (4) and (5) are winsorized at the 1\% and 99\% levels to mitigate the influence of outliers.

\subsection{The association between excess endowments and the program expense ratio}

In Table 5, we test Hypothesis 1 and present results from OLS regressions of PROG EXP RATIO on proxies for excess endowment and control variables. As described in Section 5.3, we tabulate three model specifications with different variables and functional forms for excess endowment. Fiscal year, state, and industry dummies are included in the regression models but are not tabulated. As above, in all regression

\footnotetext{
${ }^{10}$ In unreported tests, we include change in net income (either scaled by sales or assets) as an additional performance measure. Consistent with Hallock (2002), we find that this measure has no significant positive association with pay, and does not affect the inference from our excess endowment variables.
} 
specifications, we use Huber-White robust standard errors clustered by firm. These standard errors are a generalization of the White (1980) standard errors and are robust to both serial correlation and heteroskedasticity (Rogers, 1993).

In Table 5, PROG EXP RATIO is positively correlated with total expenses in all specifications. Because total expenses are the sum of program expenses, management expenses, and fundraising expenses, this finding suggests that larger firms are more efficient in that a larger fraction of each dollar of expenses goes toward program costs.

Consistent with our alternative hypothesis that excess endowments are associated with agency problems that render NFPs less efficient, we find in Column I that $P R O G$ EXP RATIO is negatively correlated with Ex Endow. This result continues to hold when we control for the relation between PROG EXP RATIO and negative excess endowments in Column II. The significant negative relation between PROG EXP RATIO and excess endowments holds for firms with positive endowments; there is no relation for firms with negative excess endowments. Finally, in Column III, we find a negative relation between PROG EXP RATIO and the large endowment indicator variable, Q4 Ex Endow. In terms of economic significance, firms in the highest quartile of excess endowment have a ratio of program service expenses to total expenses that is $1.77 \%$ smaller than firms in the bottom three quartiles of excess endowment. For the average firm in the sample, this ratio would decrease by $2.18 \%$ from $81.27 \%$ to $79.50 \%$. Overall, the results in Columns I through III in Table 5 show a negative relation between excess endowment and program expenses, which supports our alternative hypothesis that excess endowments are associated with agency problems and lower expenditures on charity. 
As discussed above, in our Table 5 regressions we control for potential incentives

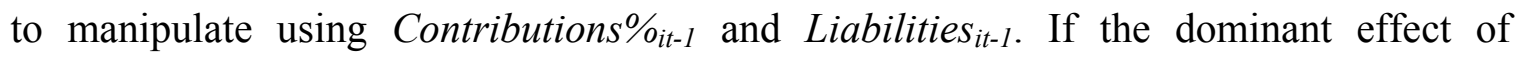
Contributions $\%_{\text {it- } 1}$ is manipulation, then we expect it to be positively associated with program expenses. Alternatively, in the absence of manipulation, firms that raise more contributions will have greater fundraising expense and lower program expense. The estimated negative coefficient on Contributions $\%$ it-1 in Table 5 suggests that this latter economic effect dominates manipulation in our sample. The estimated positive

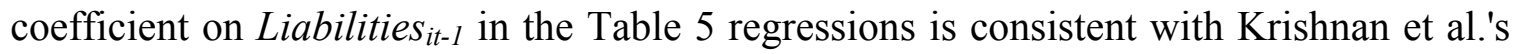
hypothesis that firms with greater financial distress engage in more manipulation. However, we note that although our findings on the relation with excess endowment hold in the presence of these controls for potential manipulation, they also hold if we remove these controls or enter them separately in our regressions.

As a second means of addressing the concern that under-endowed firms manipulate program expenses upward, we divide the sample based on expected manipulation. We follow Krishnan et al. in defining as clear "manipulators" those firms with zero fundraising expenses although they receive contributions and have no permissible reason for not reporting fundraising expenses. We then estimate separate regressions for the 16,796 "manipulators" and the 24,956 remaining observations. We find significant negative associations between excess endowment and program expenses in both subsamples (untabulated). If this relation were spuriously induced by manipulation, we would not expect to see a relation in either subsample. In addition, our results for the low-manipulation firms are virtually identical to those shown in Column III for the full sample. Overall, we find no evidence that the negative relation between 
excess endowments and program expenses is induced by manipulation; instead, the relation appears to reflect agency problems.

As discussed above, an accumulation of excess endowment funds may indicate that the firm anticipates growth opportunities. Firms with growth opportunities could have higher fundraising expenses and lower program expenses, and for these firms, we could observe a negative association between excess endowments and program expenses for reasons unrelated to agency problems. Although our results above suggest growth opportunities are not the reason for excess endowment for most firms, it is conceivable that our finding of a negative relation between excess endowment and efficiency could be driven by the minority of excess endowment firms that show substantial growth. To address this concern, in Table 5 - Column VI, we divide firms with excess endowment into those with Transitory Ex Endow and Persistent Ex Endow. As described above, these variables require data on one-year-ahead endowment. This requirement reduces the sample size to 32,949 observations and is the reason we do not include these variables in the main tests. As shown in Column VI, we find that both Persistent Ex Endow and Transitory Ex Endow are associated with lower PROG EXP RATIO, confirming that our results hold within the subsample of firms that is not characterized by growth opportunities. $^{11}$

\section{Insert Table 5 here}

\subsection{The Association between Excess Endowments and Compensation}

In Tables 6 and 7, we test Hypothesis 2 and present results from OLS regressions of the compensation variables on proxies for excess endowment and control variables.

\footnotetext{
${ }^{11}$ If we also include the one-year-ahead realized percentage change in program expenses as an additional proxy for growth opportunities, the inference is the same.
} 
Table 6 first examines the relation between excess endowments and CEO compensation, CEO COMP.

Consistent with Hallock (2002), we find in all specifications that CEO COMP is positively associated with contributions and with our size proxy, total expenses. ${ }^{12} \mathrm{We}$ also find a positive coefficient on Zero Contributions. The magnitude of the coefficient on Zero Contributions indicates that CEOs who raise no contributions earn about the same compensation as CEOs who raise an average amount of funds. ${ }^{13}$

As in Table 5, we again use multiple measures of excess endowment in our Tables 6 and 7 regressions. In Column I, we use a continuous excess endowment variable (Ex Endow) as a proxy for the presence of agency problems. Consistent with our prediction in Hypothesis 2, CEO COMP exhibits a positive association with excess endowment, and is significant at a $10 \%$ level. The coefficient indicates that compensation increases by $3.6 \%$ when excess endowment increases by one standard deviation. Column II presents the results with the continuous excess endowment variable separately for firms with positive and negative excess endowments. Consistent with Hypothesis 2, the estimated coefficient for excess endowment is positive and statistically significant for positive endowment firms. Also consistent with our predictions, and the intuition in Opler et al. (1999), we find no significant relation between excess endowment and CEO compensation for negative endowment firms. Column III shows that the significant positive relation between excess endowments and $C E O C O M P$ is robust to using $Q 4 E x$

\footnotetext{
${ }^{12}$ Hallock uses total assets as a size proxy, but this variable is confounded in our tests by the fact that total assets are larger when endowments are larger. We obtain very similar results if we use the logarithm of "normal" assets (assets less abnormal endowment) instead of expenses in the regression model.

${ }^{13}$ The coefficient on Zero Contributions is 0.36 , which is similar to the 0.37 compensation effect for CEOs with average contributions. ( 0.37 is equal to the product of the 0.03 coefficient on Log Contributions and the 12.47 average log contribution). One explanation for this finding is that the CEOs who raise no funds manage firms in which contributions are not important and therefore not used as a performance measure.
} 
Endow as a proxy for large excess endowments (coded as ' 1 ' for firms in the top quartile of excess endowment in a given year). In terms of economic significance, firms in the highest quartile of excess endowment pay their CEOs approximately $8 \%$ more than firms in the bottom three quartiles. ${ }^{14}$

An alternative explanation for our finding that CEO compensation and excess endowment are positively correlated is that large endowments proxy for management quality, and higher quality managers receive more pay. Two major types of management quality are ability to manage growth opportunities and efficiency, either in fundraising or in managing the NFP. Our results above show that firms with excess endowments are less efficient, so the data do not support the conjecture that high-endowment managers are more efficient. Our results above also indicate growth opportunities are not the reason for excess endowments for most firms. However, it is conceivable that the positive relation between CEO compensation and excess endowment is driven by the minority of firms that do show substantial growth and who require higher quality executives to carry out this growth. To address this concern, in Column IV, we again divide firms with excess endowment into those with Transitory Ex Endow and Persistent Ex Endow. As described above, this requirement reduces the sample size to 32,763 observations. As shown in Column IV, we find that both Persistent Ex Endow and Transitory Ex Endow are associated with higher CEO compensation, confirming that our results hold within the subsample of firms that is not characterized by growth opportunities. ${ }^{15}$

\footnotetext{
${ }^{14}$ If we substitute the program expense ratio for excess endowment in the compensation regression, we find that firms with a higher program ratio pay lower compensation. This negative association is consistent with agency problems being manifested by low program expense ratios and high compensation.

${ }^{15}$ If we also include the one-year-ahead realized percentage change in program expenses as an additional proxy for growth opportunities, the inference is the same.
} 


\section{Insert Table 6 here}

Table 7 presents results with $O \& D C O M P \%$ as a proxy for agency costs. Our controls for size and performance are significant and of the predicted sign. ${ }^{16}$ Consistent with Hypothesis 2 , the results in Column I show that $O \& D C O M P \%$ is positively related to Ex Endow. Column II shows that there is a significant positive association between compensation and Ex Endow when there is an excess of endowment, and an unexpected negative association when there is a deficit of endowment. One interpretation of this negative relation for low endowments is that firms with extremely low endowments require executives that are highly skilled in fundraising, and that it requires more effort and talent to run an under-endowed institution. A second interpretation is that firms with very small endowments are near distress, and compensation is higher to reflect additional termination risk.

Column III shows a positive relation between $O \& D C O M P \%$ and the indicator variable for large excess endowments, implying that officers and directors of firms in the top quartile of excess endowment receive higher pay. In terms of economic significance, firms in the extreme quartile of excess endowment have a $0.40 \%$ greater ratio of officer and director compensation to expenses compared to the firms in the bottom three quartiles. An increase of $0.40 \%$ in the officer and director pay ratio implies a $14 \%$ rise in the average $O \& D C O M P \%$ of $2.89 \%$.

Finally, in Column IV, we divide firms with excess endowment into those with

\footnotetext{
${ }^{16}$ Note our finding that larger firms pay less officer and director compensation as a percentage of expenses is consistent with our results in Table 6 , which show a coefficient of 0.30 when $\log$ (compensation) is regressed on $\log ($ size). This means that compensation increases at a decreasing rate with firm size, which implies that pay as a fraction of expenses decreases as expenses increase. Regression analysis (not tabulated) shows that we obtain the same inference if we instead use log of O\&D compensation as a dependent variable.
} 
Transitory Ex Endow and Persistent Ex Endow in order to assure that our results are not driven by firms with substantial growth. We find that both Persistent Ex Endow and Transitory Ex Endow are associated with higher $O \& D C O M P \%$, indicating that our results hold for the substantial majority of firms that are not using endowment to finance growth, and reinforcing our hypothesis that excess endowments are associated with agency problems. ${ }^{17}$

\section{Insert Table 7 here}

In summary, the results in Tables 6 and 7 show a positive relation between excess endowment and both CEO as well officer and director compensation. These findings corroborate our findings in Table 5 that excess endowments are associated with agency problems.

\section{Robustness tests}

Our measure of endowment assumes that all of the funds in the endowment are equally accessible to management and equally give rise to potential agency problems. In fact, many NFPs have endowments with assets that are restricted to specific uses by donors, such as certain capital projects or serving the needs of specific clientele (e.g., scholarships for low-income students). Restricted assets may limit the discretion of management with respect to these funds, thereby lowering potential agency problems. In addition, donors may put restrictions on assets in settings where agency problems are known to be large. On the other hand, restrictions can impede the efficient functioning of the charity. For example, if restrictions are too tight, these assets are not useful as precautionary savings, and total endowment holdings must be greater as a result.

\footnotetext{
${ }^{17}$ If we also include the one-year-ahead realized percentage change in program expenses as an additional proxy for growth opportunities, the inference is the same.
} 
Although we have no clear prediction on the relation between restricted assets and agency problems, we re-estimate our measure of excess endowments from Table 2 and our regressions in the Column III of Tables 5, 6, and 7 after eliminating the portion of endowment assets that is restricted. We compute Unrestricted_Endow as unrestricted assets (line 67) deflated by total expenses (line 17). These data come from a separate NCCS "digitized" database that contains more detail from Form 990s but is available only for the period of 1998 to 2001 . This data requirement reduces the sample to 16,381 observations. We report these results in Table 8. On this smaller sample, we find that our results are qualitatively the same as those shown in Tables 5 to 7: Unrestricted excess endowment exhibits a significant negative association with program expenses, and significant positive associations with both CEO compensation and officer and director compensation. However, the coefficient magnitudes of these associations appear to be larger than those shown above.

\section{Insert Table 8 here}

Our final robustness check considers the sensitivity of our results to the exclusion of healthcare organizations, which are primarily hospitals and comprise over forty percent of our sample. As noted by Weisbrod (1988) and Fisman and Hubbard (2002), healthcare appears to be systematically different from other NFP activities. In particular, hospitals face for-profit competition and may behave more like for-profit organizations. Second, hospitals are significant issuers of tax-exempt debt and use the proceeds of these issuances to increase their endowments (Gentry, 2002). Consistent with the approach in Fisman and Hubbard (2002), to ensure that our results are not driven by these organizations, we remove them from the sample and re-estimate our model of excess 
endowments. We then use the residuals from this model to re-run our tests in Tables 5, 6, and 7. The results for the full sample are qualitatively similar to those reported above for program expenses and CEO compensation, i.e., firms in the top quartile of excess endowments have significantly lower program expenses and significantly higher CEO compensation. The results for officer and director compensation are weaker: the relation between the top quartile of excess endowment and pay is positive, but not significant. When we omit health-care organizations from the analysis of unrestricted excess endowments, however, the results are qualitatively similar to those shown in Table 8: firms in the top quartile of excess endowments have significantly lower program expenses and significantly higher CEO compensation and officer and director compensation.

\section{Conclusion}

In this paper, we examine agency problems in NFPs arising from excess holdings of endowment assets. Previous research explores agency costs of excess cash holdings in for-profit firms, and although the evidence is somewhat mixed, researchers generally find that excess cash is associated with excessive acquisitions and investment. Compared to cash holdings in for-profit firms, NFPs hold substantially greater assets in their endowments. Further, NFPs do not have obvious residual claimants with a strong interest and ability to monitor management, and unlike for-profits, it is generally not feasible for NFPs to return excess assets to donors. However, the ability of NFP managers to extract rents through acquisitions is also very limited. Although Hansmann (1990) conjectures the existence of agency problems with excess endowments, and Fisman and Hubbard (2002) model optimal endowment levels, it is an open and interesting empirical question 
as to whether NFP excess endowment holdings result in agency problems.

Our tests are designed to distinguish between three alternative explanations for excess endowments: (1) growth opportunities, (2) monitoring, or (3) agency problems. Inconsistent with large endowments anticipating greater firm-specific growth opportunities, we find that most firms with excess endowments maintain their excess endowments for several years, and that firms with persistent excess endowments do not exhibit higher growth in program expenses or investments. Inconsistent with better monitoring, we find that program expenditures toward the charitable good are lower for firms with excess endowments. We also provide evidence that excess CEO pay and total officer and director pay are greater for firms with excess endowments. Overall, we find that excess endowments are associated with greater agency problems.

Corporate governance and executive compensation in NFPs has come under intense scrutiny in recent years, and there is increasing concern about these issues among regulators. For example, in his June 22, 2004 testimony to the U.S. Senate Committee on Finance, Mark W. Everson, Commissioner of Internal Revenue, stated:

The issues of governance and executive compensation are closely intertwined. We are concerned that the governing boards of tax-exempt organizations are not, in all cases, exercising sufficient diligence as they set compensation for the leadership of the organizations. There have been numerous recent reports of executives of both private foundations and public charities who are receiving unreasonably large compensation packages.

Beginning in the summer of 2004, the IRS undertook an aggressive investigation of nonprofit governance, as well as the practices nonprofits use to set compensation. Our finding that excessive executive compensation is more pervasive at NFPs with excess endowments provides insight into the types of not-for-profit organizations where governance and executive compensation are less likely to stand up to scrutiny. 


\section{References}

Baber, W., Daniel, P., and A. Roberts, 2002. Compensation to managers of charitable organizations, an empirical study of the role of accounting measures of program activities. Accounting Review 77, 679-694.

Bertrand, M., and S. Mullanaithan, 2003. Enjoying the quiet life? Corporate governance and managerial preferences. Journal of Political Economy 111, 1043-1075.

Blanchard, O., Lopez-de-Silanes, F., and A. Shleifer, 1994. What do firms do with cash windfalls? Journal of Financial Economics 36, 337-360.

Callen, J., Klein, A., and D. Tinkelman, 2003. Board composition, committees, and organizational efficiency: The case of nonprofits. Nonprofit and Voluntary Sector Quarterly 32, 493-524.

Desai, M., and R. Yetman, 2005. Constraining managers without owners: Governance of the not-for-profit enterprise, working paper, Harvard University.

Everson, M., 2004. IRS Commissioner testimony: Charitable giving problems and best practices. IR-2004-81, June 22. www.IRS.gov/newsroom.

Fama, E., and M. Jensen, 1983. Separation of ownership and control. Journal of Law and Economics 26, 301-325.

Fisman, R., and G. Hubbard, 2002. Governance, endowments, and the nonprofit form, working paper, Columbia University.

Gentry, W., 2002. Debt, investment and endowment accumulation: The case of not-forprofit hospitals. Journal of Health Economics 21, 845-872.

Hallock, K., 2002. Managerial pay and governance in American nonprofits. Industrial Relations 41, $377-406$.

Hansmann, H., 1980. The role of non-profit enterprise. Yale Law Journal 89, 835-901.

Hansmann, H., 1990. Why do universities have endowments? Journal of Legal Studies $19,3-42$.

Hansmann, H., 1996. The Ownership of Enterprise. Cambridge: Harvard University Press.

Harford, J., 1999. Corporate cash reserves and acquisitions. Journal of Finance 54, 1969-1997.

Jensen, M., 1986. Agency costs of free cash flow, corporate finance, and takeovers. 
American Economic Review 76, 323-29.

Krishnan, R., Yetman, M., and R. Yetman, 2004. Cost Shifting in Nonprofit Organizations: An Agency Based Analysis. Working paper, the University of California at Davis.

Myers, S., and N. Majluf, 1984. Corporate financing and investment decisions when firms have information that investors do not have, Journal of Financial Economics 13, $187-222$.

Opler, T., Pinkowitz, L., Stulz, R., and R. Williamson, 1999. The determinants and implications of corporate cash holdings. Journal of Financial Economics 52, 3$\underline{46 .}$

Pinkowitz, L., and R. Williamson, 2004. What is a dollar worth? The market value of cash holdings, working paper, Georgetown University.

Posnett, J., and T. Sandler, 1989. Demand for charity donations in private non-profit markets. Journal of Public Economics 40, 187-200.

Rogers, W., 1993. Regression standard errors in clustered samples. Stata Technical Bulletin Reprints, vol. 3., College Station, Texas: Stata Press, 83-94.

Tinkelman, D., 1998. Differences in sensitivity of financial statement users to joint cost allocations: The case of nonprofit organizations. Journal of Accounting, Auditing \& Finance, 13, 377-394.

Tinkelman, D., 1999. Factors affecting the relation between donations to not-for-profit organizations and an efficiency ratio. Research in Governmental and Nonprofit Accounting 10.

Weisbrod, B., 1988. The Nonprofit Economy. Cambridge: Harvard University Press.

Weisbrod, B., and N. Dominguez, 1986. Demand for collective goods in private nonprofit markets, Can fund-raising expenditures help overcome free-rider behavior? Journal of Public Economics 30, 83-95.

White, H., 1980. A heteroskedasticity-consistent covariance matrix estimator and a direct test for heteroskedasticity. Econometrica 48, 817-838. 
Table 1 - Descriptive Statistics by Industry

\begin{tabular}{|c|c|c|c|c|c|c|c|c|c|}
\hline & $\begin{array}{c}\% \text { of Total } \\
\text { Observations }\end{array}$ & Endow/Exp & $\begin{array}{c}\text { Revenue } \\
\text { (\$ millions) }\end{array}$ & $\begin{array}{c}\text { Expenses } \\
\text { (\$ millions) }\end{array}$ & $P P E G R \%$ & $\begin{array}{c}\text { PROGRAM } \\
G R \%\end{array}$ & $\begin{array}{c}\text { PROG EXP } \\
\text { RATIO }\end{array}$ & $\begin{array}{l}\text { CEO COMP } \\
\text { (\$ thousands) }\end{array}$ & $\begin{array}{c}O \& D \\
C O M P \%\end{array}$ \\
\hline \multicolumn{10}{|c|}{ Industry Descriptive } \\
\hline Arts & 6.57 & 1.34 & 8.36 & 6.21 & 0.04 & 0.04 & 75.64 & 142.39 & 3.07 \\
\hline Education & 26.10 & 1.06 & 22.18 & 18.80 & 0.07 & 0.05 & 83.16 & 156.25 & 1.59 \\
\hline Health & 35.62 & 0.24 & 59.01 & 55.77 & 0.06 & 0.05 & 86.38 & 215.52 & 0.71 \\
\hline Human services & 13.13 & 0.40 & 9.66 & 9.13 & 0.05 & 0.05 & 86.39 & 104.14 & 1.59 \\
\hline Other & 18.58 & 0.66 & 8.30 & 7.09 & 0.03 & 0.05 & 83.07 & 128.25 & 2.65 \\
\hline \multicolumn{10}{|c|}{ Sample Descriptive } \\
\hline Mean & & 2.01 & 63.21 & 58.12 & 0.11 & 0.07 & 81.27 & 203.11 & 2.89 \\
\hline STD & & 4.36 & 121.89 & 114.12 & 0.25 & 0.19 & 14.34 & 174.17 & 4.67 \\
\hline Median & & 0.49 & 20.67 & 18.21 & 0.05 & 0.05 & 84.41 & 157.50 & 1.36 \\
\hline
\end{tabular}

This table presents median descriptive statistics by industry for a sample of 41,752 not-for-profit firm-year observations. The four major industries follow the National Taxonomy of Exempt Entities (NTEE) industry classification. The table also presents mean, standard deviation and median descriptive statistics for the total sample. Endow/Exp is the sum of cash, savings, and investment securities (line 45, column (b) + line 46, column (b) + line 54 , column (b)) deflated by total expenses (line 17). Revenue is the total revenue (line 12) in millions of dollars. Expenses is the total expenses (line 17) in millions of dollars. PPE GR is the change in land, buildings, and equipment (line $57 \mathrm{a}$, column (b)) plus depreciation (line 42, column (a)) from year $\mathrm{t}-1$ to $\mathrm{t}$ (one year) and from $\mathrm{t}-1$ to $\mathrm{t}+1$ (two years). We deflate PPE GR by total expenses (line 17) at year t-1, and multiply it by 100 to express it as a percentage of total expenses. $P R O G R A M G R$ is the change in total program services expenses (line 13) from year t-1 to t (one year) and from t-1 to t+1 (two years). We deflate $P R O G R A M$ GR by total expenses (line 17) at year t-1, and multiply it by 100 to express it as a percentage of total expenses. PROG EXP RATIO is total program services expenses (line 13 ) as a percentage of total expenses (line 17). CEO COMP is total CEO compensation (Form $990-$ Part V, column (c) + column (d) + column (e)) in thousands of dollars. $O \& D C O M P \%$ is officer and director compensation (line 25, column (a)) as a percentage of total expenses (line 17). 
Table 2 - Determinants of Benchmark Endowment

\begin{tabular}{|c|c|c|c|}
\hline \multirow{2}{*}{ Variable } & \multirow{2}{*}{$\begin{array}{l}\text { Predicted } \\
\text { Sign }\end{array}$} & \multicolumn{2}{|c|}{ Dep. Variable: Endow/Expt } \\
\hline & & $\mathrm{I}$ & II \\
\hline Intercept & & $\begin{array}{c}7.34 * * * \\
(7.98)\end{array}$ & $\begin{array}{c}9.27 * * * \\
(10.69)\end{array}$ \\
\hline$C V R E V_{\mathrm{t}}$ & + & $\begin{array}{c}11.56^{* * * *} \\
(18.86)\end{array}$ & $\begin{array}{c}10.20 * * * \\
(17.41)\end{array}$ \\
\hline Log Revenue $_{\mathrm{t}}$ & - & $\begin{array}{c}-0.41 * * * \\
(-11.52)\end{array}$ & $\begin{array}{c}-0.42 * * * \\
(-12.08)\end{array}$ \\
\hline Access to Debt ${ }_{\mathrm{t}}$ & - & $\begin{array}{c}-0.49 * * * \\
(-3.72)\end{array}$ & $\begin{array}{c}-0.40 * * * \\
(-3.13)\end{array}$ \\
\hline$C V R E V *$ Access to Debt ${ }_{\mathrm{t}}$ & - & $\begin{array}{c}-6.75^{* * *} \\
(-10.08)\end{array}$ & $\begin{array}{c}-6.35^{* * *} \\
(-9.82)\end{array}$ \\
\hline$L A B O R \%{ }_{\mathrm{t}}$ & - & & $\begin{array}{c}-4.55 * * * \\
(-14.67)\end{array}$ \\
\hline R-square (\%) & & 23.71 & 26.61 \\
\hline Observations & & 41,752 & 41,752 \\
\hline
\end{tabular}

This table presents the results of an OLS model of the determinants of benchmark endowment. Endow/Exp is the sum of cash, savings, and investment securities (line 45, column (b) + line 46, column (b) + line 54, column (b)) deflated by total expenses (line 17). CVREV is the coefficient of variation of total revenue (line 12) measured as the ratio of the standard deviation of total revenue to mean total revenue, both measured in the last five years ending at year $t$. We delete observations with less than four years of data (among the last five years) available to compute the coefficient of variation of total revenues. Log Revenue is the natural logarithm of total revenue (line 12). Access to Debt is an indicator variable coded ' 1 ' if the firm in year t has obtained debt in the last ten years ending at year t. We categorize a firm as having debt if it has tax-exempt bond liabilities (line 64a, column (b)) or mortgages and other notes payable (line 64b, column (b)). LABOR\% is the total compensation for all employees including salaries, pension plan contributions, benefits and taxes (lines $25+26+27+28+$ 29 , column (a)) as a percentage of total expenses (line 17). Industry, state, and year dummies are included in the model but not tabulated in the results. T-statistics based on Huber-White robust standard errors are presented in parentheses below coefficient estimates. ${ }^{*}, *$, and $* * *$ indicate two-tailed statistical significance at 10,5 , and 1 percent levels. 
Table 3 - Persistence of Excess Endowment

\begin{tabular}{|c|c|c|c|c|}
\hline \multirow{2}{*}{$\begin{array}{l}\text { Time since firm } \\
\text { enters top quartile of } \\
\text { excess endowment }\end{array}$} & \multicolumn{4}{|c|}{ Percentage of firms in quartile of excess endowment } \\
\hline & Quartile 1 & Quartile 2 & Quartile 3 & Quartile 4 \\
\hline \multirow[t]{2}{*}{ Year 0} & & & & 3,034 \\
\hline & & & & $100.0 \%$ \\
\hline \multirow[t]{2}{*}{ Year 1} & 59 & 80 & 428 & 1,678 \\
\hline & $2.6 \%$ & $3.6 \%$ & $19.1 \%$ & $74.7 \%$ \\
\hline \multirow[t]{2}{*}{ Year 2} & 85 & 101 & 378 & 1,226 \\
\hline & $4.8 \%$ & $5.6 \%$ & $21.1 \%$ & $68.5 \%$ \\
\hline \multirow[t]{2}{*}{ Year 3} & 92 & 87 & 320 & 932 \\
\hline & $6.4 \%$ & $6.1 \%$ & $22.4 \%$ & $65.2 \%$ \\
\hline \multirow[t]{2}{*}{ Year 4} & 72 & 85 & 258 & 764 \\
\hline & $6.1 \%$ & $7.2 \%$ & $21.9 \%$ & $64.8 \%$ \\
\hline \multirow[t]{2}{*}{ Year 5} & 69 & 74 & 206 & 574 \\
\hline & $7.5 \%$ & $8.0 \%$ & $22.3 \%$ & $62.2 \%$ \\
\hline
\end{tabular}

This table examines the persistence of excess endowment for firms in the highest excess endowment quartile. Firms are ranked into quartiles every year based on the excess level of endowment (Ex Endow) at year t. Ex Endow is the residual from the determinants of benchmark endowment regression (Table 2), where endowment is the sum of cash, savings, and investment securities (line 45, column (b) + line 46, column (b) + line 54, column (b)) deflated by total expenses (line 17). Firms are selected based on the first time they enter the highest quartile of excess endowment. The firms are followed for the next five years to determine the quartile in which they belong in the subsequent years. Quartile 4 represents the highest excess endowment quartile, and Year 0 is the starting measurement year. The number of firm years in each quartile, each year, is presented and the percentage of firms is in italics. 
Table 4 - Determinants of Investment and Growth in Program Expenses

\begin{tabular}{|c|c|c|c|c|c|c|}
\hline \multirow{2}{*}{ Variable } & \multicolumn{3}{|c|}{ Dep. Variable: $P P E G R \%$} & \multicolumn{3}{|c|}{ Dep. Variable: PROGRAM GR\% } \\
\hline & 1-Year & 1-Year & 2-Year & 1-Year & 1-Year & 2-Year \\
\hline Intercept & $\begin{array}{c}15.46^{* * *} \\
(3.21)\end{array}$ & $\begin{array}{c}14.50^{* * *} \\
(3.73)\end{array}$ & $\begin{array}{c}40.33^{* * *} \\
(3.93)\end{array}$ & $\begin{array}{c}24.27^{* * *} \\
(12.39)\end{array}$ & $\begin{array}{c}25.51^{* * *} \\
(11.93)\end{array}$ & $\begin{array}{r}47.35^{* * *} \\
(12.13)\end{array}$ \\
\hline $\log _{\text {Expenses }}$ t-1 $_{1}$ & $\begin{array}{l}-0.30 * * \\
(-2.26)\end{array}$ & $\begin{array}{c}-0.40 * * * \\
(-2.69)\end{array}$ & $\begin{array}{c}-1.16^{* * *} \\
(-3.57)\end{array}$ & $\begin{array}{l}-1.23 * * * \\
(-14.60)\end{array}$ & $\begin{array}{l}-1.36^{* * *} \\
(-13.92)\end{array}$ & $\begin{array}{l}-2.42 * * * \\
(-13.78)\end{array}$ \\
\hline Q4 Ex Endow t-1 $_{\mathrm{t}}$ & $\begin{array}{c}1.58 * * * \\
(3.74)\end{array}$ & & & $\begin{array}{c}2.24 * * * \\
(8.88)\end{array}$ & & \\
\hline Persistent Ex Endow ${ }_{\mathrm{t}-1}$ & & $\begin{array}{c}0.06 \\
(0.11)\end{array}$ & $\begin{array}{c}0.26 \\
(0.24)\end{array}$ & & $\begin{array}{l}0.69^{* *} \\
(2.42)\end{array}$ & $\begin{array}{l}-0.16 \\
(-0.35)\end{array}$ \\
\hline Transitory Ex Endow ${ }_{\mathrm{t}-1}$ & & $\begin{array}{c}5.12 * * * \\
(6.27)\end{array}$ & $\begin{array}{c}9.89 * * * \\
(6.33)\end{array}$ & & $\begin{array}{l}7.04^{* * *} \\
(11.68)\end{array}$ & $\begin{array}{r}15.86^{* * *} \\
(14.56)\end{array}$ \\
\hline $\begin{array}{l}\text { Industry, state, and year } \\
\text { dummies }\end{array}$ & Yes & Yes & Yes & Yes & Yes & Yes \\
\hline R-square (\%) & 3.02 & 3.33 & 4.49 & 1.91 & 2.70 & 4.76 \\
\hline Observations & 41,752 & 32,949 & 32,949 & 41,752 & 32,949 & 32,949 \\
\hline
\end{tabular}

This table presents the results of an OLS model of the determinants of PPE GR\% and PROGRAM GR\%. PPE $G R$ is the change in land, buildings, and equipment (line 57a, column (b)) plus depreciation (line 42, column (a)) from year $\mathrm{t}-1$ to $\mathrm{t}$ (one year) and from $\mathrm{t}-1$ to $\mathrm{t}+1$ (two years). We deflate PPE GR by total expenses (line 17) at year t-1, and multiply it by 100 to express it as a percentage of total expenses. PROGRAM GR is the change in total program services expenses (line 13) from year $\mathrm{t}-1$ to $\mathrm{t}$ (one year) and from $\mathrm{t}-1$ to $\mathrm{t}+1$ (two years). We deflate PROGRAM GR by total expenses (line 17) at year $\mathrm{t}-1$, and multiply it by 100 to express it as a percentage of total expenses. Log Expenses is the natural logarithm of total expenses (line 17). Q4 Ex Endow is an indicator variable coded as ' 1 ' if the excess endowment at year t-1 is in the top quartile of the distribution, and ' 0 ' otherwise. Persistent Ex Endow is an indicator variable coded as ' 1 ' if the excess endowment at year t-1 is in the top quartile of the distribution and remains in the top quartile of the distribution at year $\mathrm{t}+1$, and ' 0 ' otherwise. Transitory Ex Endow is an indicator variable coded as ' 1 ' if the excess endowment at year t-1 is in the top quartile of the distribution and not in the top quartile of the distribution at year $\mathrm{t}+1$, and ' 0 ' otherwise. Tstatistics based on Huber-White robust standard errors are presented in parentheses below coefficient estimates. $*, * *$, and $* * *$ indicate two-tailed statistical significance at 10,5 , and 1 percent levels. 


\section{Table 5 - Determinants of the Program Expense Ratio}

\begin{tabular}{|c|c|c|c|c|c|}
\hline \multirow{2}{*}{ Variable } & \multirow{2}{*}{$\begin{array}{l}\text { Predicted } \\
\text { Sign }\end{array}$} & \multicolumn{4}{|c|}{ Dep. Variable: PROG EXP RATIO } \\
\hline & & I & II & III & IV \\
\hline Intercept & & $\begin{array}{c}48.80 * * * \\
(12.99)\end{array}$ & $\begin{array}{c}50.37^{* * * *} \\
(13.30)\end{array}$ & $\begin{array}{c}47.68 * * * \\
(12.64)\end{array}$ & $\begin{array}{c}45.23^{* * * *} \\
(10.64)\end{array}$ \\
\hline Log Expenses $_{\mathrm{t}-1}$ & + & $\begin{array}{c}2.06^{* * *} \\
(17.11)\end{array}$ & $\begin{array}{l}1.98 * * * \\
(16.60)\end{array}$ & $\begin{array}{c}2.15^{* * *} \\
(17.10)\end{array}$ & $\begin{array}{l}2.31 * * * \\
(15.85)\end{array}$ \\
\hline Contributions $\%_{\mathrm{t}-1}$ & $?$ & $\begin{array}{c}-3.37 * * * \\
(-5.03)\end{array}$ & $\begin{array}{c}-3.31 * * * \\
(-4.94)\end{array}$ & $\begin{array}{c}-2.93 * * * \\
(-4.37)\end{array}$ & $\begin{array}{c}-3.27 * * * \\
(-4.15)\end{array}$ \\
\hline Liabilities $_{\mathrm{t}-1}$ & $?$ & $\begin{array}{l}1.20 * * \\
(2.16)\end{array}$ & $\begin{array}{l}1.20 * * \\
(2.14)\end{array}$ & $\begin{array}{c}1.53 * * * \\
(2.73)\end{array}$ & $\begin{array}{l}1.24 * \\
(1.88)\end{array}$ \\
\hline Ex Endow ${ }_{\mathrm{t}-1}$ & - & $\begin{array}{c}-0.36^{* * *} \\
(-5.29)\end{array}$ & & & \\
\hline Positive Ex Endow ${ }_{\mathrm{t}-1}$ & - & & $\begin{array}{c}-0.42 * * * \\
(-4.55)\end{array}$ & & \\
\hline Negative Ex Endow ${ }_{\mathrm{t}-1}$ & 0 & & $\begin{array}{c}-0.16 \\
(-1.34)\end{array}$ & & \\
\hline Q4 Ex Endow ${ }_{\mathrm{t}-1}$ & - & & & $\begin{array}{c}-1.77 * * * \\
(-5.08)\end{array}$ & \\
\hline Persistent Ex Endow ${ }_{\mathrm{t}-1}$ & - & & & & $\begin{array}{c}-1.94 * * * \\
(-4.20)\end{array}$ \\
\hline Transitory Ex Endow ${ }_{\mathrm{t}-1}$ & - & & & & $\begin{array}{c}-1.16^{* * *} \\
(-2.93)\end{array}$ \\
\hline $\begin{array}{l}\text { Industry, state, } \\
\text { and year dummies }\end{array}$ & & Yes & Yes & Yes & Yes \\
\hline R-square (\%) & & 12.63 & 12.67 & 12.19 & 12.62 \\
\hline Observations & & 41,752 & 41,752 & 41,752 & 32,949 \\
\hline
\end{tabular}

This table presents the results of an OLS model of the determinants of PROG EXP RATIO. PROG EXP RATIO is total program services expenses (line 13) as a percentage of total expenses (line 17). Log Expenses is the natural logarithm of total expenses (line 17). Contributions $\%$ is the ratio of total contributions (line 1d) to total revenue (line 12) and Liabilities is the ratio of total liabilities (line 66) to total assets (line 59). Ex Endow is the excess level of endowment at year t- 1 measured as the residual of the regression of determinants of benchmark endowment (Table 3), where endowment is the sum of cash, savings, and investment securities (line 45, column (b) + line 46, column (b) + line 54, column (b)) deflated by total expenses (line 17). Positive (Negative) Ex Endow is Ex Endow if Ex Endow is positive (negative or 0), and '0' otherwise. 


\section{Table 5 - Cont'd}

Q4 Ex Endow is an indicator variable coded as ' 1 ' if the excess endowment at year t-1 is in the top quartile of the distribution, and ' 0 ' otherwise. Persistent Ex Endow is an indicator variable coded as ' 1 ' if the excess endowment at year $\mathrm{t}-1$ is in the top quartile of the distribution and remains in the top quartile of the distribution at year $\mathrm{t}+1$, and ' 0 ' otherwise. Transitory Ex Endow is an indicator variable coded as ' 1 ' if the excess endowment at year t-1 is in the top quartile of the distribution and not in the top quartile of the distribution at year $\mathrm{t}+1$, and ' 0 ' otherwise. T-statistics based on Huber-White robust standard errors are presented in parentheses below coefficient estimates. ${ }^{*},{ }^{* *}$, and $* * *$ indicate two-tailed statistical significance at 10,5 , and 1 percent levels. 
Table 6 - Determinants of CEO Compensation

\begin{tabular}{|c|c|c|c|c|c|}
\hline \multirow{2}{*}{ Variable } & \multirow{2}{*}{$\begin{array}{l}\text { Predicted } \\
\text { Sign }\end{array}$} & \multicolumn{4}{|c|}{ Dep. Variable: $C E O C O M P_{\mathrm{t}}$} \\
\hline & & $\mathrm{I}$ & II & III & IV \\
\hline Intercept & & $\begin{array}{l}6.27 * * * \\
(56.45)\end{array}$ & $\begin{array}{l}6.22 * * * \\
(53.08)\end{array}$ & $\begin{array}{l}6.28^{* * *} \\
(56.27)\end{array}$ & $\begin{array}{r}6.35^{* * *} \\
(51.11)\end{array}$ \\
\hline Log Expenses $_{\mathrm{t}-1}$ & + & $\begin{array}{c}0.30^{* * *} \\
(52.04)\end{array}$ & $\begin{array}{l}0.30^{* * *} \\
(49.45)\end{array}$ & $\begin{array}{r}0.30^{* * *} \\
(51.89)\end{array}$ & $\begin{array}{l}0.29 * * * \\
(44.41)\end{array}$ \\
\hline Log Contributions $_{\mathrm{t}}$ & + & $\begin{array}{c}0.03 * * * \\
(7.69)\end{array}$ & $\begin{array}{c}0.03 * * * \\
(7.59)\end{array}$ & $\begin{array}{c}0.03 * * * \\
(7.34)\end{array}$ & $\begin{array}{c}0.03 * * * \\
(7.09)\end{array}$ \\
\hline Zero Contributions $_{\mathrm{t}}$ & $?$ & $\begin{array}{c}0.36^{* * *} \\
(5.97)\end{array}$ & $\begin{array}{c}0.35^{* * *} \\
(5.82)\end{array}$ & $\begin{array}{c}0.34 * * * \\
(5.64)\end{array}$ & $\begin{array}{c}0.36^{* * *} \\
(5.45)\end{array}$ \\
\hline Ex Endow $w_{\mathrm{t}-1}$ & + & $\begin{array}{l}0.01^{*} \\
(1.93)\end{array}$ & & & \\
\hline Positive Ex Endow $w_{\mathrm{t}-1}$ & + & & $\begin{array}{l}0.01^{* *} \\
(2.03)\end{array}$ & & \\
\hline Negative Ex Endow $w_{\mathrm{t}-1}$ & 0 & & $\begin{array}{l}-0.00 \\
(-0.38)\end{array}$ & & \\
\hline Q4 Ex Endow ${ }_{\mathrm{t}-1}$ & + & & & $\begin{array}{c}0.08^{* * *} \\
(5.52)\end{array}$ & \\
\hline Persistent Ex Endow ${ }_{\mathrm{t}-1}$ & + & & & & $\begin{array}{c}0.07 * * * \\
(3.79)\end{array}$ \\
\hline Transitory Ex Endow ${ }_{\mathrm{t}-1}$ & + & & & & $\begin{array}{c}0.08 * * * \\
(4.08)\end{array}$ \\
\hline $\begin{array}{l}\text { Industry, state, and year } \\
\text { dummies }\end{array}$ & & Yes & Yes & Yes & Yes \\
\hline R-square (\%) & & 47.52 & 47.53 & 47.63 & 46.37 \\
\hline Observations & & 41,752 & 41,752 & 41,752 & 32,949 \\
\hline
\end{tabular}

This table presents the results of an OLS model of the determinants of CEO Compensation (CEO COMP). CEO COMP is the natural logarithm of CEO compensation (Form $990-$ Part V, column (c) + column (d) + column (e)). Log Expenses is the natural logarithm of total expenses (line 17). Log Contributions is the natural logarithm of total contributions (line 1d). This variable is set to zero if total contributions equal zero. Zero Contributions is an indicator variable coded as ' 1 ' if total contributions equal zero, and ' 0 ' otherwise. Ex Endow is the excess level of endowment at year t-1 measured as the residual of the regression of determinants of benchmark endowment (Table 3), where endowment is the sum of cash, savings, and investment securities (line 45, column (b) + line 46, column (b) + line 54, column (b)) deflated by total expenses (line 17). Positive (Negative) Ex Endow is Ex Endow if Ex Endow is positive (negative or 0), and '0' otherwise. 


\section{Table 6 - Cont'd}

Q4 Ex Endow is an indicator variable coded as ' 1 ' if the excess endowment at year t-1 is in the top quartile of the distribution, and ' 0 ' otherwise. Persistent Ex Endow is an indicator variable coded as ' 1 ' if the excess endowment at year $\mathrm{t}-1$ is in the top quartile of the distribution and remains in the top quartile of the distribution at year $\mathrm{t}+1$, and ' 0 ' otherwise. Transitory Ex Endow is an indicator variable coded as ' 1 ' if the excess endowment at year $\mathrm{t}-1$ is in the top quartile of the distribution and not in the top quartile of the distribution at year $\mathrm{t}+1$, and ' 0 ' otherwise. T-statistics based on Huber-White robust standard errors are presented in parentheses below coefficient estimates. ${ }^{*},{ }^{* *}$, and $* * *$ indicate two-tailed statistical significance at 10,5 , and 1 percent levels. 
Table 7 - Determinants of Officer and Director Compensation

\begin{tabular}{|c|c|c|c|c|c|}
\hline \multirow{2}{*}{ Variable } & \multirow{2}{*}{$\begin{array}{l}\text { Predicted } \\
\text { Sign }\end{array}$} & \multicolumn{4}{|c|}{ Dep. Variable: $O \& D C O M P \% o_{\mathrm{t}}$} \\
\hline & & I & II & III & IV \\
\hline Intercept & & $\begin{array}{c}30.13 * * * \\
(24.53)\end{array}$ & $\begin{array}{c}28.23 * * * \\
(23.60)\end{array}$ & $\begin{array}{c}30.18^{* * *} * \\
(24.58)\end{array}$ & $\begin{array}{c}29.61 * * * \\
(20.17)\end{array}$ \\
\hline Log Expenses $_{\mathrm{t}-1}$ & - & $\begin{array}{c}-1.65 * * * \\
(-37.57)\end{array}$ & $\begin{array}{c}-1.55 * * * \\
(-37.23)\end{array}$ & $\begin{array}{c}-1.66^{* * * *} \\
(-37.60)\end{array}$ & $\begin{array}{c}-1.61 * * * \\
(-32.52)\end{array}$ \\
\hline Log Contributions $_{\mathrm{t}}$ & + & $\begin{array}{c}0.09 * * * \\
(4.24)\end{array}$ & $\begin{array}{c}0.08 * * * \\
(3.71)\end{array}$ & $\begin{array}{c}0.09 * * * \\
(3.97)\end{array}$ & $\begin{array}{c}0.09 * * * \\
(3.86)\end{array}$ \\
\hline Zero Contributions $_{\mathrm{t}}$ & $?$ & $\begin{array}{c}1.97 * * * \\
(5.75)\end{array}$ & $\begin{array}{c}1.73 * * * \\
(5.07)\end{array}$ & $\begin{array}{c}1.91 * * * \\
(5.47)\end{array}$ & $\begin{array}{c}1.97 * * * \\
(5.12)\end{array}$ \\
\hline Ex Endow ${ }_{\mathrm{t}-1}$ & + & $\begin{array}{c}0.04 * * \\
(2.01)\end{array}$ & & & \\
\hline Positive Ex Endow ${ }_{\mathrm{t}-1}$ & + & & $\begin{array}{c}0.12 * * * \\
(4.92)\end{array}$ & & \\
\hline Negative Ex Endow ${ }_{\mathrm{t}-1}$ & 0 & & $\begin{array}{c}-0.20 * * * \\
(-5.48)\end{array}$ & & \\
\hline Q4 Ex Endow $w_{\mathrm{t}-1}$ & + & & & $\begin{array}{c}0.40^{* * *} \\
(4.72)\end{array}$ & \\
\hline Persistent Ex Endow ${ }_{\mathrm{t}-1}$ & + & & & & $\begin{array}{c}0.41 * * * \\
(3.86)\end{array}$ \\
\hline Transitory Ex Endow ${ }_{\mathrm{t}-1}$ & + & & & & $\begin{array}{c}0.36^{* * * *} \\
(3.55)\end{array}$ \\
\hline $\begin{array}{l}\text { Industry, state, and year } \\
\text { dummies }\end{array}$ & & Yes & Yes & Yes & Yes \\
\hline R-square (\%) & & 34.89 & 35.31 & 34.94 & 34.33 \\
\hline Observations & & 41,752 & 41,752 & 41,752 & 32,949 \\
\hline
\end{tabular}

This table presents OLS models of the determinants of Officer and Director Compensation (O\&D COMP\%). $O \& D C O M P \%$ is officer and director compensation(line 25 , column (a)) as a percentage of total expenses (line 17). Log Expenses is the natural logarithm of total expenses (line 17). Log Contributions is the natural logarithm of total contributions (line 1d). This variable is set to zero if total contributions equal zero. Zero Contributions is an indicator variable coded as ' 1 ' if total contributions equal zero, and ' 0 ' otherwise. Ex Endow is the excess level of endowment at year t-1 measured as the residual of the regression of determinants of benchmark endowment (Table 3), where endowment is the sum of cash, savings, and investment securities (line 45, column (b) + line 46, column (b) + line 54, column (b)) deflated by total expenses (line 17). Positive (Negative) Ex Endow is Ex Endow if Ex Endow is positive (negative or 0), and '0' otherwise. 


\section{Table 7 - Cont'd}

Q4 Ex Endow is an indicator variable coded as ' 1 ' if the excess endowment at year t-1 is in the top quartile of the distributions, and ' 0 ' otherwise. Persistent Ex Endow is an indicator variable coded as ' 1 ' if the excess endowment at year $\mathrm{t}-1$ is in the top quartile of the distribution and remains in the top quartile of the distribution at year $\mathrm{t}+1$, and ' 0 ' otherwise. Transitory Ex Endow is an indicator variable coded as ' 1 ' if the excess endowment at year t-1 is in the top quartile of the distribution and not in the top quartile of the distribution at year $\mathrm{t}+1$, and ' 0 ' otherwise. T-statistics based on Huber-White robust standard errors are presented in parentheses below coefficient estimates. ${ }^{*},{ }^{* *}$, and $* * *$ indicate two-tailed statistical significance at 10,5 , and 1 percent levels. 
Table 8 - Alternative Endowment Measure - Unrestricted Assets

\begin{tabular}{|c|c|c|c|}
\hline \multirow{2}{*}{ Variable } & \multicolumn{3}{|c|}{ Dependent Variable } \\
\hline & PROG EXP RATIO & СЕО СОМР & $O \& D C O M P \%$ \\
\hline Intercept & $\begin{array}{c}48.25 * * * \\
(12.29)\end{array}$ & $\begin{array}{l}6.00^{* * *} \\
(49.34)\end{array}$ & $\begin{array}{c}30.08^{* * *} \\
(27.00)\end{array}$ \\
\hline Log Expenses Ex-1 $_{1}$ & $\begin{array}{l}1.90^{* * *} \\
(15.24)\end{array}$ & $\begin{array}{l}0.32 * * * \\
(50.03)\end{array}$ & $\begin{array}{r}-1.71 * * * \\
(-34.09)\end{array}$ \\
\hline Log Contributions $_{\mathrm{t}}$ & & $\begin{array}{c}0.02 * * * \\
(5.03)\end{array}$ & $\begin{array}{l}0.05^{* *} \\
(2.14)\end{array}$ \\
\hline Zero Contributions $\mathrm{t}_{\mathrm{t}}$ & & $\begin{array}{c}0.26^{* * *} \\
(3.80)\end{array}$ & $\begin{array}{c}1.65^{* * *} \\
(3.72)\end{array}$ \\
\hline Contributions $\%_{\mathrm{t}-1}$ & $\begin{array}{c}-2.21 * * * \\
(-3.35)\end{array}$ & & \\
\hline Liabilities $_{\mathrm{t}-1}$ & $\begin{array}{l}1.04 * \\
(1.78)\end{array}$ & & \\
\hline Q4 Ex Unrestricted ${ }_{\mathrm{t}-1}$ & $\begin{array}{c}-3.34 * * * \\
(-8.36)\end{array}$ & $\begin{array}{c}0.15^{* * * *} \\
(9.33)\end{array}$ & $\begin{array}{c}0.57 * * * \\
(4.95)\end{array}$ \\
\hline $\begin{array}{l}\text { Industry, state, and year } \\
\text { dummies }\end{array}$ & Yes & Yes & Yes \\
\hline R-square & 13.32 & 51.81 & 37.50 \\
\hline Observations & 16,381 & 16,381 & 16,381 \\
\hline
\end{tabular}

This table presents the results of an OLS model of the determinants of management and general expenses (PROG EXP RATIO), CEO Compensation (CEO COMP), and Officer and Director Compensation (O\&D $C O M P \%$ ) using an alternative endowment measure. This data is available for the period of 1998 to 2001 . Unrestricted_Endow is unrestricted assets (line 67) deflated by total expenses (line 17). We measure excess Unrestricted_Endow as the residual of an endowment model equivalent to the specification in Table 3. Q4 Ex Unrestricted is an indicator variable coded as ' 1 ' if the excess Unrestricted_Endow at year t-1 is in the top quartile of the distributions and ' 0 ' otherwise. All other variables are defined as before. T-statistics based on Huber-White robust standard errors are presented in parentheses below coefficient estimates. *, **, and *** indicate two-tailed statistical significance at 10, 5, and 1 percent levels. 